Pobrane z czasopisma Annales I - Philosophy and Sociology http://philosophia.annales.umcs.pl Data: 26/04/2023 14:49:10

DOI: $10.17951 / i .2018 .43 .1 .193-213$

A N N A LES

UNIVERSITATIS MARIAE CURIE-SKŁODOWSKA

LUBLIN - POLONIA

VOL. XLIII, 1

SECTIO I

2018

PRZEMYSŁAW WROCHNA

ORCID ID: https://orcid.org/0000-0002-3827-4918

Uniwersytet Marii Curie-Skłodowskiej w Lublinie

Ryzyko ekologiczne jako ryzyko społeczne.

Na ile „rzeczywista” jest katastrofa klimatyczna?

Ecological Risk as a Social Risk. How "Real" Is the Climate Catastrophe?

\title{
WPROWADZENIE
}

Zainteresowanie kwestiami ekologicznymi jest zróżnicowane czasowo i społecznie'. Jego wzrost można obserwować od połowy lat 70. XX w. Najczęściej jest on kojarzony z pewnym ,przesunięciem” aksjonormatywnym (od wartości materialnych do ,postmaterialnych”), a także z narastaniem różnorodnych form ryzyka wiązanych z przemianami środowiska naturalnego.

Określenia „oswajanie natury” czy „podporządkowanie przyrody” oznaczały niegdyś pozytywną próbę organizacji otoczenia przez człowieka i pozwalały mu korzystać z dobrodziejstw natury (co warunkowało jego przetrwanie). Dzisiaj jednak aspekt „uspołeczniania środowiska naturalnego" skorelowany został z jego degradacją, która w przyszłości może się przyczynić do szeregu negatywnych dla człowieka konsekwencji.

$\mathrm{Z}$ tego powodu ryzyko związane z ekologią - czy samymi zmianami klimatycznymi - nabiera szczególnego znaczenia. To właśnie ze względu na ożywioną dzisiaj debatę publiczną, która toczy się wokół tego problemu, nieistniejąca (jeszcze) przyszłość materializuje się w teraźniejszości na poziomie obaw, deklaracji, sporów i działań. Niniejszy artykuł stanowi próbę odpowiedzi na pytania: Jaka jest społeczna percepcja ryzyka klimatycznego? Jakie znaczenia są nadawane temu problemowi? Jacy aktorzy biorą udział w tym procesie?

1 M. Bell, An Invitation to Environmental Sociology, Thousand Oaks 1998. 
Pobrane z czasopisma Annales I - Philosophy and Sociology http://philosophia.annales.umcs.pl Data: 26/04/2023 14:49:10

\section{POJĘCIE RYZYKA}

Problematyka ryzyka jest od lat podejmowana na polu różnych dyscyplin naukowych. W ekonomii pojęcie to wiązane jest z działaniami rynkowymi (potencjalnego zysku lub straty). Nauki medyczne koncentrują się wokół prawdopodobieństwa wystąpienia jakiegoś zjawiska (np. choroby), podobnie do innych dziedzin przyrodniczych. Psychologia wskazuje na indywidualne sposoby percepcji i wynikające $z$ nich stany emocjonalne oraz postawy.

Socjologia odnosi się do źródeł ryzyka i mechanizmów jego „funkcjonowania" na polu społecznym. W kwestii definicyjnej zwraca uwagę na specyficzny charakter i konotacje tego pojęcia. Ryzyko bowiem immanentnie wiąże się z niepewnością, tj. z sytuacjami, których efekt jest trudny do przewidzenia lub wręcz niemożliwy. Termin ten zwraca się zatem ku przyszłości, dotyczy jej kolonizowania, ponieważ wszystkie debaty toczone na temat ryzyka są w istocie antycypacją przyszłości ${ }^{2}$. W tym sensie ryzyko należy rozważać jako możliwość wystąpienia negatywnego zdarzenia, co podkreśla również duński socjolog J. Arnoldi, według którego ryzyko nie jest zagrożeniem per se, lecz potencjalnością tego zagrożenia ${ }^{3}$ (chociaż w literaturze przedmiotu terminy te często są używane zamiennie).

Dyskurs nauk społecznych często określa ryzyko jako efekt przeobrażeń nowoczesnego społeczeństwa oraz zachodzących w nim aktualnie zjawisk i procesów, np. kryzys gospodarczy, podobny do tego z 2008 r., nie byłby możliwy 300 lat wcześniej, ponieważ nie istniały wtedy choćby społeczeństwa oparte na konsumpcji, przepływ kapitałowy między krajami i instytucjami finansowymi nie był tak znaczący oraz nie istniała odpowiednia infrastruktura technologiczna. Czy zatem uznawanie ryzyka za domenę współczesności jest jak najbardziej zasadne?

Tezie tej wtóruje brytyjski naukowiec A. Giddens i podkreśla, że jeśli mamy na myśli np. ,wymiar życia jednostki, to pod względem przeciętnej długości życia i zapadalności na poważne choroby, ludzie w społeczeństwach rozwiniętych są w dużo bezpieczniejszej sytuacji niż większość populacji w minionych epokach"4. Zdaniem Giddensa ryzyko od zawsze stanowiło element ludzkiej egzystencji, przede wszystkim dla tradycyjnych społeczeństw, każdego dnia konfrontujących się z nieprzewidywalną naturą, pozbawionych odpowiedniego dostępu do wiedzy i zaplecza technicznego.

2 Zob. W.D. Rowe, An “Anatomy” of Risk, Environmental Protection Agency, Washington 1977, s. 35.

J. Arnoldi, Ryzyko, Warszawa 2011, s. 34.

4 A. Giddens, Nowoczesność i tożsamość. „Ja” i spoleczeństwo w epoce późnej nowoczesności, Warszawa 2012, s. 156. 
Pobrane z czasopisma Annales I - Philosophy and Sociology http://philosophia.annales.umcs.pl Data: 26/04/2023 14:49:10

Ryzyko ekologiczne jako ryzyko społeczne...

Zauważa to także U. Beck, wyróżniając trzy typy potencjalnych niebezpieczeństw właściwe dla konkretnych okresów historycznych. Niemiecki socjolog wymienia na wstępie przedindustrialne zagrożenia, które nie wynikają z ekonomicznych i technologicznych działań i są zewnętrzne wobec społeczeństwa. To wszelkiego rodzaju zjawiska naturalne (klęski żywiołowe, epidemie), których sprawstwo niekiedy przypisywane było losowi, fatum czy bogom ${ }^{5}$.

Druga kategoria to ryzyko epoki przemysłowej, które - w przeciwieństwie do przeszłych zrządzeń - jest produktem społecznych działań. Takie ryzyko podlega kalkulacji i definicji akademickiej dzięki odkryciu rachunku prawdopodobieństwa i późniejszemu rozwojowi statystyki jako dziedziny naukowej ${ }^{6}$. Ten „probabilistyczny model” ryzyka ${ }^{7}$ koncentrował się na istnieniu w rzeczywistości szeregu różnych prawidłowości. Według metody następstwa wielu zdarzeń mogą być one sprowadzone do kwantytatywnych obliczeń i w ten sposób są poddane trafnym przewidywaniom. Rachunek prawdopodobieństwa dał społeczeństwom możliwość zredukowania zgeneralizowanej niepewności ${ }^{8}$. Jak pisze Arnoldi, probabilistyka „umożliwia wysuwanie twierdzeń o możliwości przyszłych zagrożeń [...]. Prawdopodobieństwo, można powiedzieć, przekształca przyszłą niepewność w rozpoznawane przez naukę ryzyko" ". Zastosowanie metod statystycznych do opisu i analizy zjawisk o charakterze masowym pozwoliło przekształcić „prostą procedurę gromadzenia informacji w potężne, złożone narzędzie interpretacji świata [...] roztaczającego się wokół nas" ${ }^{\prime 10}$.

Trzecia grupa, zdaniem Becka, to tzw. wielkie zagrożenia późnej nowoczesności, które stanowią niejako syntezę ryzyka przedindustrialnego i epoki przemysłowej. Dzieje się tak dlatego, że współczesne ryzyko (podobnie jak to przednowoczesne) broni się przed trafnymi antycypacjami naukowymi, lecz (tak jak możliwe zagrożenia epoki industrialnej) pochodzi z wnętrza systemu społecznego i jest efektem rozwoju technologicznego i cywilizacyjnego ${ }^{11}$. W ten sposób klaruje się obraz rzeczywistości określanej mianem ,społeczeństwa ryzyka"12.

5 Zob. U. Beck, Gegengifte. Die organisierte Unverantwortlichkeit, Frankfurt am Main 1988, s. 120.

6 Ibidem, s. 121.

7 P. Strydom, Risk, Environment and Society: Ongoing Debates, Current Issues and Future Prospects, Philadelphia 2002.

8 U. Beck, E. Grande, Europa kosmopolityczna. Spoleczeństwo i polityka w drugiej nowoczesności, Warszawa 2009.

9 J. Arnoldi, op. cit., s. 41.

10 P.L. Bernstein, Przeciw bogom. Niezwykte dzieje ryzyka, Warszawa 2011, s. 66.

11 U. Beck, Gegengifte..., s. 121.

12 Idem, Społeczeństwo ryzyka. W drodze do innej nowoczesności, Warszawa 2002. 
Pobrane z czasopisma Annales I - Philosophy and Sociology http://philosophia.annales.umcs.pl Data: 26/04/2023 14:49:10

\section{SPOŁECZEŃSTWO RYZYKA KLIMATYCZNEGO}

Zdaniem Becka to właśnie obecne społeczeństwo (szczególnie w swojej zaawansowanej formie) konstytuuje ryzyko. Rozwój cywilizacyjny przyczynił się bowiem do wyklarowania wielu potencjalnych zagrożeń (społecznych, politycznych, gospodarczych i zdrowotnych) niewystępujących w przeszłości. W parze z tą konstytucją idzie także pewna świadomość ryzyka, które przestaje być obliczalne i kontrolowalne przez naukowe ekspertyzy. Za symboliczny moment wyłonienia się kategorii społeczeństwa ryzyka uznaje się tragiczną awarię elektrowni atomowej w Czarnobylu - największą katastrofę w historii energetyki jądrowej w XX w. Ujawnienie kruchości systemów bezpieczeństwa stosowanych w przypadku energii jądrowej pozwoliło na dostrzeżenie możliwych obszarów zagrożeń środowiskowych i społecznych, będących wynikiem rozwoju technologiczno-przemysłowego.

Według autora tej koncepcji świadomość ryzyka anihilowała „kształt naszego dotychczasowego życia, odzwierciedlając uzależnienie światowego systemu industrialnego od zintegrowanej przemysłowo i zatrutej natury"13. To wszystko zachwiało poczuciem zaufania wobec naukowców i ekspertów, a do grona aktorów „rozstrzygających" o kwestiach związanych z ryzykiem i bezpieczeństwem zaczęli stopniowo dołączać politycy, przedsiębiorcy, ruchy społeczne, media oraz opinia publiczna. Płaszczyznami zaś, na których materializuje się aktualnie ryzyko, są takie elementy rzeczywistości, jak: ekonomia/gospodarka (ryzyko niewydolności systemu gospodarczego, kryzys ekonomiczny, defraudacje i przestępstwa finansowe, załamanie rynku pracy), polityka (podważenie legitymizacji systemu demokratycznego, w tym możliwość totalitarnego sposobu sprawowania władzy), zdrowie (choroby cywilizacyjne: otyłość, cukrzyca, nowotwory i depresja, uzależnienia behawioralne), indywidualna biografia (wybór właściwej ścieżki edukacji i kariery, stylu życia i adekwatnej diety, kwestie związane z życiem rodzinnym i intymnym) czy środowisko (degradacja przyrody, skażenie rzek i zanieczyszczenie powietrza, katastrofa klimatyczna, w tym powszechne klęski przyrodnicze).

Warto wskazać, iż dzisiejsza rzeczywistość coraz bardziej zacieśnia się globalnie, zatem ryzyko staje się też „światowe”. Jak zauważa Giddens, globalizacja oznacza, iż „,W coraz większym stopniu wszyscy żyjemy w »jednym świecie«, a co za tym idzie jednostki, grupy i narody są coraz silniej wzajemnie od siebie uzależnione" ${ }^{14}$. Zdarzenia w jednej części świata wywołują konsekwencje w jego drugiej części, czego przykładem są ostatnie kryzysy gospodarcze, np. wielkie

13 Ibidem, s. 13.

14 A. Giddens, Socjologia, Warszawa 2006, s. 74. 
Pobrane z czasopisma Annales I - Philosophy and Sociology http://philosophia.annales.umcs.pl Data: 26/04/2023 14:49:10

Ryzyko ekologiczne jako ryzyko społeczne...

załamanie rynków finansowych w 2008 r. Globalne ryzyko jest wyrazem globalnych współzależności i postępuje proporcjonalnie do zaciskania tych supłów.

Innych egzemplifikacji może dostarczyć omawiana w tej pracy kwestia ryzyka klimatycznego, która - jak wskazuje Beck - posiada cechy modelowe „ryzyka światowego"'15. Dzisiejsze (zglobalizowane) potencjalne zagrożenia mają charakter „demokratyczny”. Dzieje się tak dlatego, że ryzyko, przecinając granice państw i kontynentów, zagraża wszystkim w podobnym stopniu, bez względu na wyznanie, rodzaj wykonywanej pracy i posiadane wykształcenie. Zdaniem niemieckiego socjologa globalne ryzyko cechują: delokalizacja, niekalkulowalność oraz nieodwracalność (nierekompensowalność). Delokalizacja w tym przypadku oznacza wspomnianą wyżej „demokratyczność”. Ryzyko nie jest przypisane sztywno do konkretnego miejsca (delokalizacja przestrzenna), ale także do okresu (delokalizacja czasowa ${ }^{16}$ ) i procesu (delokalizacja społeczna ${ }^{17}$ ), dlatego swobodnie przecina te płaszczyzny. Niekalkulowalność odnosi się natomiast do niemożności uzyskania pewnej wiedzy na temat nowych obszarów ryzyka, które dotyczą np. wprowadzanych technologii (klonowanie czy ingerencja w ludzki genom) bądź wydarzeń bez precedensu (zmiany klimatyczne). Wreszcie nieodwracalność (lub nierekompensowalność) zwraca uwagę na „katastroficzny” charakter ryzyka, którego skutki jawią się jako ciężkie lub niemożliwe do odwrócenia (np. świat po wojnie nuklearnej).

Takim typem ryzyka jest z pewnością współczesny problem zmian klimatu. Według raportu opracowanego przez Międzynarodowy Zespół ds. Zmian Klimatu (Intergovernmental Panel on Climate Change - IPCC) ,atmosfera i ocean ogrzały się, zmalały masy śniegu i lodu, poziom oceanów podniósł się, a stężenie gazów cieplarnianych w atmosferze wzrosło [...]. Na półkuli północnej okres 1983-2012 był prawdopodobnie najcieplejszym 30-leciem podczas ostatnich 1400 lat"18. W wyniku tych zmian lądolody Grenlandii i Antarktydy tracą swoją objętość, przyczyniając się do wzrostu tempa zwiększania się poziomu oceanów i mórz. W tym samym czasie w atmosferze wzrósł stopień koncentracji dwutlenku węgla $\left(\mathrm{CO}_{2}\right)$, tlenku azotu $(\mathrm{NO})$ i metanu $\left(\mathrm{CH}_{4}\right)$ do niespotykanego od 800 tys. lat poziomu ${ }^{19}$, będący przyczyną ogólnego wzrostu temperatury globalnej.

15 U. Beck, Społeczeństwo światowego ryzyka. W poszukiwaniu utraconego bezpieczeństwa, Warszawa 2012.

16 Kwestia ta odnosi się do okresu latencji wielu negatywnych zdarzeń. Oznacza to, że niektóre efekty i reperkusje tych wydarzeń są znacznie oddalone w czasie, jak np. choroby popromienne osób, które przeżyły eksplozję bomb jądrowych w Hiroszimie i Nagasaki.

17 Ryzyko jest efektem różnorodnych zjawisk i procesów, wzajemnie się przecinających, dlatego nie da się dokładnie określić ich przyczyn i konsekwencji.

18 IPCC, Zmiany klimatu 2013. Fizyczne podstawy naukowe, http://ipcc.ch/pdf/reports-nonUN-translations/polish/ar5-wg1-spm.pdf [dostęp: 20.11.2017], s. 2-3.

19 Ibidem, s. 9. 
Pobrane z czasopisma Annales I - Philosophy and Sociology http://philosophia.annales.umcs.pl Data: 26/04/2023 14:49:10

Zgodnie z raportem stan dwutlenku węgla w atmosferze w największym stopniu jest wynikiem spalania paliw kopalnych (ropy, węgla kamiennego i brunatnego) oraz zmian w użytkowaniu gruntów. Zdaniem autorów odpowiedzialność za ten fakt ponoszą niewątpliwie ludzie, którzy są dominującymi emitentami $\mathrm{CO}_{2}$ od początku ery przemysłowej. Dalsze zwiększanie emisji gazów cieplarnianych będzie sprzyjać pogłębianiu globalnego ocieplenia, zmniejszaniu masy lodowców, a tym samym zwiększaniu poziomu mórz. IPCC formułuje różne scenariusze dotyczące przyszłości, wskazując, iż w różnych regionach świata ocieplenie klimatu może mieć odmienne oblicza, m.in. czekać nas będą częstsze i coraz dłuższe fale upałów oraz zwiększy się prawdopodobieństwo powodzi. Dodatkowo widoczne będą zmiany w ilości i strukturze samych opadów atmosferycznych (susze lub nadmierne opady), zmiany w intensywności oraz częstotliwości negatywnych zjawisk pogodowych (burze, huragany). Zmiany będą także wywoływać skutki w systemach: społecznym, politycznym i gospodarczym (np. konflikty o dostęp do zasobów naturalnych, obciążenie gospodarcze poprzez walkę ze zmianami klimatycznymi, problem tzw. uchodźców klimatycznych).

Jednak, jak podkreśla Giddens, ,,scenariusze dotyczą możliwych wersji przyszłości, trudno więc dziwić się, że niektórzy je kwestionują"20. Sceptycy stawiają tezy, że zmiany klimatyczne przebiegają w umiarkowanym stopniu bądź nie są wywołane przez człowieka ${ }^{21}$. Duński naukowiec B. Lomborg wskazuje przykładowo na istotniejsze problemy, którymi powinien zajmować się świat, jak bieda, głód, AIDS i broń nuklearna ${ }^{22}$, natomiast dziennikarze Ch. Booker i R. North sugerują, że żyjemy w „erze zabobonów” czy „epoce strachów”23. Dla tych autorów procesy klimatyczne są naturalnym etapem życia Ziemi, cyklem, który występował w przeszłości (przed pojawieniem się człowieka) oraz występuje teraz. Co prawda, tzw. globalny ruch negujący raporty dotyczące zmian klimatycznych jest w zdecydowanej mniejszości, ale nie zmienia to faktu, iż odnosi odwrotnie proporcjonalne sukcesy, ponieważ według badań jeden na czterech Polaków (27\%) nie jest pewny, czy klimat w ogóle się zmienia, dla 63\% respondentów wzrost dwutlenku węgla to naturalne zjawisko powodowane m.in. przez oceany i rośliny, a niemalże połowa badanych (42\%) widzi w tym zjawisku biznes, na którym określone grupy zarabiają pieniądze ${ }^{24}$.

\footnotetext{
20 A. Giddens, Katastrofa klimatyczna, Warszawa 2010, s. 31.

${ }^{21}$ F. Singer, D. T. Avery, Unstoppable Global Warming, New York 2007.

22 B. Lomborg, Cool It, New York 2007.

23 A. Giddens, Katastrofa..., s. 33.

24 Stan środowiska i zmiany klimatu, „CBOS. Komunikat z Badań” 2016, nr 39, http://cbos. pl/SPISKOM.POL/2016/K_039_16.PDF [dostęp: 20.11.2017], s. 8.
} 
Pobrane z czasopisma Annales I - Philosophy and Sociology http://philosophia.annales.umcs.pl Data: 26/04/2023 14:49:10

Ryzyko ekologiczne jako ryzyko społeczne...

199

\section{RYZYKO OBIEKTYWNE CZY SUBIEKTYWNE?}

Jak zostało już wskazane, współczesne ryzyko wymyka się trafnym naukowym sposobom szacunku oraz często bywa „prognozowanym scenariuszem”, przez co staje się przedmiotem ożywionej debaty, sprzeciwów sceptyków oraz politycznych sporów i społecznych konfliktów. Paradoksalnie wraz ze wzrostem tej zgeneralizowanej niepewności zwiększa się również percepcja potencjalnych zagrożeń. Dzieje się tak, gdyż myślenie w kategoriach ryzyka „określa nasze oczekiwania, opanowuje nasze myśli i kieruje naszymi rękami, i dlatego staje się siłą [...] zmieniającą świat"25. Przykładem tego jest przede wszystkim rosnąca liczba aktorów partycypujących w procesie orzekania na temat tego, co jest ryzykiem, a co nim nie jest.

Kolejną ważną właściwością tej rzeczywistości jest - co podkreśla M. Douglas - względne zatarcie rozróżnienia między faktycznym (fizycznym) ryzykiem a jego percepcją ${ }^{26}$. Jak wskazuje Beck, „ważniejsze staje się, kto i dlaczego wierzy w ryzyko niż wymyślne scenariusze prawdopodobieństwa opracowane przez ekspertów. Mówiąc inaczej: zbadanie przez nauki społeczne kulturowych postrzeżeń ryzyka staje się sprawą centralną" ${ }^{27}$. Według tez powyższych badaczy to, jakie rozróżniamy rodzaje możliwych niebezpieczeństw, jest zależne w dużej mierze od światopoglądu i wartości kulturowych, jakie wyznajemy. W tym sensie ryzyko może być postrzegane „co najmniej na tyle sposobów, ile występuje różnic światopoglądowych i kulturowych. Łatwo zauważyć też, że odmienności w ocenie [...] biegną wzdłuż istniejących podziałów politycznych"28, ale też tych społecznych i gospodarczych.

W tym miejscu polski socjolog P. Cichocki stawia pytanie o to, jakie znaczenie „przypisuje się poszczególnym rozpoznanym i nierozpoznanym zagrożeniom”29. W odpowiedzi twierdzi, że ,źródeł owej dynamiki, postrzegania i interpretacji ryzyka należy poszukiwać w autonomicznie pojmowanym porządku społecznym" 30 . Świadomość ryzyka formowana jest tym samym w kontekście kognitywnym, politycznym i kulturowym. Cichocki zaznacza, że to społecznie i kulturowo wytwarzane systemy wiedzy (naukowej i potocznej) oraz stosunki władzy wpływają na to, jak zostaje zdefiniowana rzeczywistość.

\footnotetext{
U. Beck, Społeczeństwo światowego ryzyka..., s. 23.

M. Douglas, A. Wildavsky, Risk and Culture, Berkeley 1983.

U. Beck, E. Grande, op. cit., s. 316.

J. Arnoldi, op. cit., s. 19.

29 P. Cichocki, Konteksty społeczeństwa ryzyka, Poznań 2005, s. 48.

30 Ibidem.
} 
Pobrane z czasopisma Annales I - Philosophy and Sociology http://philosophia.annales.umcs.pl Data: 26/04/2023 14:49:10

Można to stwierdzić chociażby na podstawie analizy raportów Eurobarometru, realizowanych na zlecenie Komisji Europejskiej. Zgodnie z badaniami dla 1/3 Polaków, głównymi niepokojami są: zdrowie i bezpieczeństwo socjalne (31\%), rosnące koszty życia (27\%) oraz wysokość wynagrodzenia za pracę (25\%). Kwestie związane ze środowiskiem naturalnym i klimatem (5\%) w opinii Polaków nie stanowią istotnego problemu dla naszego kraju.

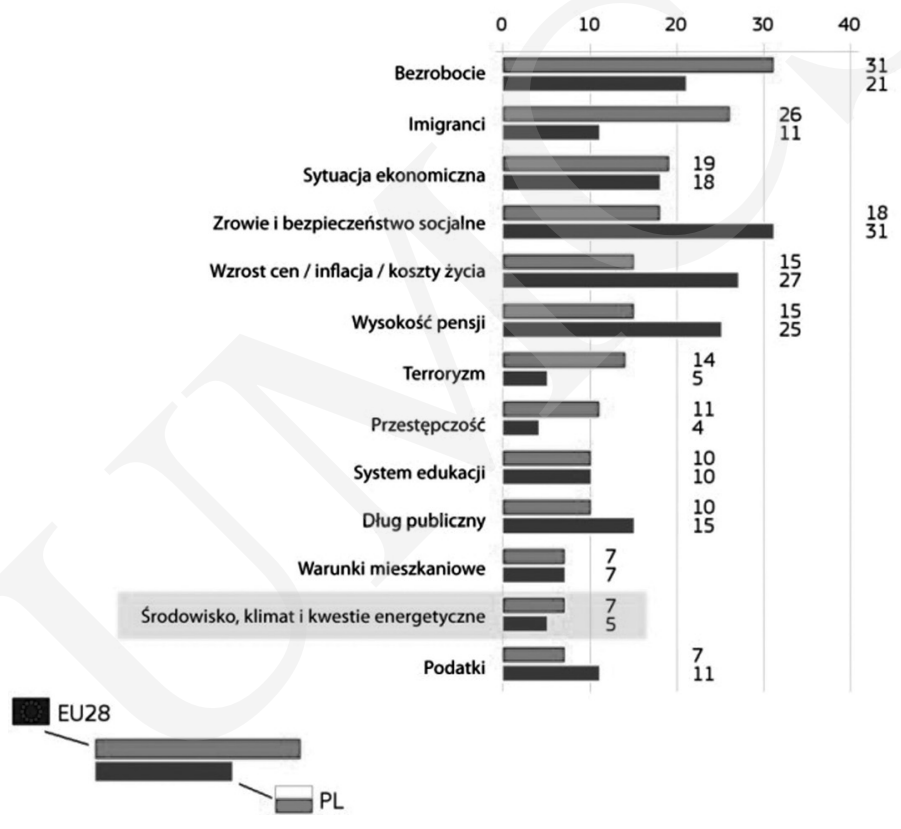

Rys. 1. Jakie są najważniejsze problemy, z którymi boryka się Twój kraj (Polska) w danym czasie? (w \%)

Źródło: opracowanie własne na podstawie: Standard Eurobarometer 86, Public opinion in the European Union, https://ec.europa.eu/finland/sites/finland/files/eb86_first_en.pdf [dostęp: 20.11.2017].

Wynik ten nie odbiega od średniej europejskiej (7\%), ponieważ Unia Europejska mierzy się obecnie przede wszystkim z problemem bezrobocia (31\%) i kryzysem migracyjnym (26\%). Nie oznacza to oczywiście, że taki stan postrzegania kwestii „ekologicznych” jest reprezentowany przez każde europejskie społeczeństwo. Postawioną tezę potwierdzają np. takie narody, jak Szwecja i Dania, gdzie poziom zaniepokojenia środowiskiem i klimatem jest ponad czterokrotnie wyższy niż w Polsce i ponad trzykrotnie wyższy niż w Unii Europejskiej (Szwecja - 23\%, Dania-21\%). 
Pobrane z czasopisma Annales I - Philosophy and Sociology http://philosophia.annales.umcs.pl Data: 26/04/2023 14:49:10

Ryzyko ekologiczne jako ryzyko społeczne... 201

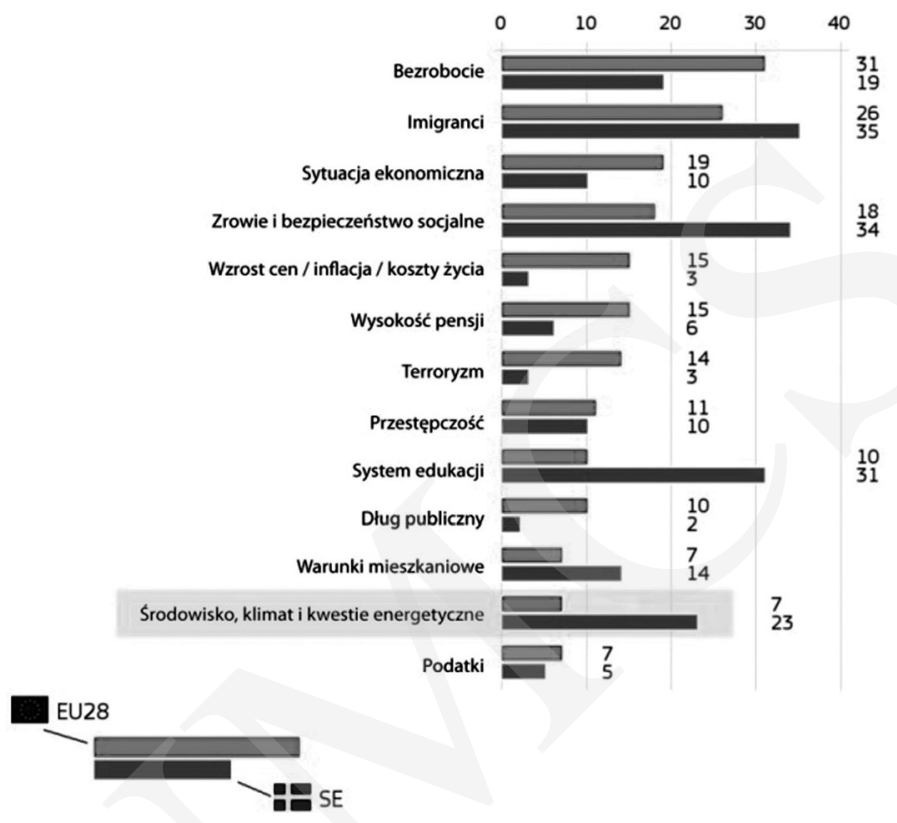

Rys. 2. Jakie są najważniejsze problemy, z którymi boryka się Twój kraj (Szwecja) w bieżącym czasie? (w \%)

Źródło: opracowanie własne na podstawie: Standard Eurobarometer 86, Public opinion in the European Union, https://ec.europa.eu/finland/sites/finland/files/eb86_first_en.pdf [dostęp: 20.11.2017].

To niezwykle duże przywiązanie do kwestii środowiskowych i klimatycznych wśród Skandynawów nie jest jednak ich najważniejszą obawą. Oba kraje borykają się obecnie z problemem imigrantów (Szwecja - 35\%, Dania - 41\%), a także żywią niepokój w stosunku do kwestii zdrowotnych (kolejno 34\% i 27\%).

Jak pokazuje powyższe zestawienie, sprawy, które dotyczą kwestii bardziej doczesnych i materialnych (fizycznych, ekonomicznych), często wypierają niepokoje o bardziej abstrakcyjnym charakterze i są odniesione do szerszej perspektywy czasowej. Kraje tzw. drugiej prędkości, zmagające się z bezrobociem, inflacją czy ogólnie z sytuacją ekonomiczną, skłonne są przywiązywać mniejszą wagę do problemów środowiskowych i klimatycznych. Wskazują na to chociażby wyniki z takich państw, jak: Litwa (2\%), Hiszpania (2\%), Łotwa (1\%), Portugalia (1\%) czy Grecja (0\%). 
Pobrane z czasopisma Annales I - Philosophy and Sociology http://philosophia.annales.umcs.pl Data: 26/04/2023 14:49:10

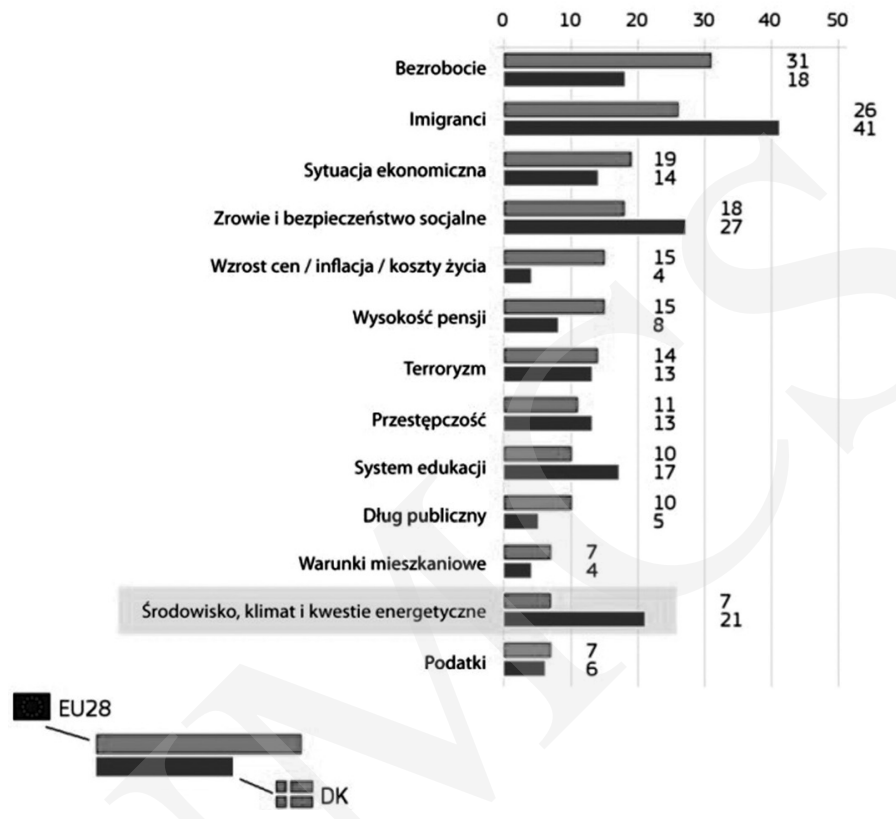

Rys. 3. Jakie są najważniejsze problemy, z którymi boryka się Twój kraj (Dania) w bieżącym czasie? (w \%)

Źródło: opracowanie własne na podstawie: Standard Eurobarometer 86, Public opinion in the European Union, https://ec.europa.eu/finland/sites/finland/files/eb86_first_en.pdf [dostęp: 20.11.2017].

Zmiana percepcji dotycząca kwestii klimatu jest również widoczna w odniesieniu do skali, jaką reprezentuje dany problem. Ryzyko klimatyczne jest przede wszystkim ryzykiem globalnym, z którym żaden indywidualny kraj czy nawet Unia Europejska jako taka nie może sobie poradzić samodzielnie. Odpowiedzialność za to możliwe zagrożenie musi wziąć na siebie ogół światowy i to ten ogół wspólnie powinien wypracować strategię działań. $Z$ tego powodu te same problemy mogą przyjmować inną wartość w odniesieniu do poziomu, w stosunku do którego są wyrażane. W odpowiedziach na pytanie o najważniejsze przyszłe zagrożenia dla całego świata zmiany klimatu znalazły się znacznie wyżej niż w skali narodowej (Polska-11\%, UE-15\%). 
Pobrane z czasopisma Annales I - Philosophy and Sociology http://philosophia.annales.umcs.pl Data: 26/04/2023 14:49:10

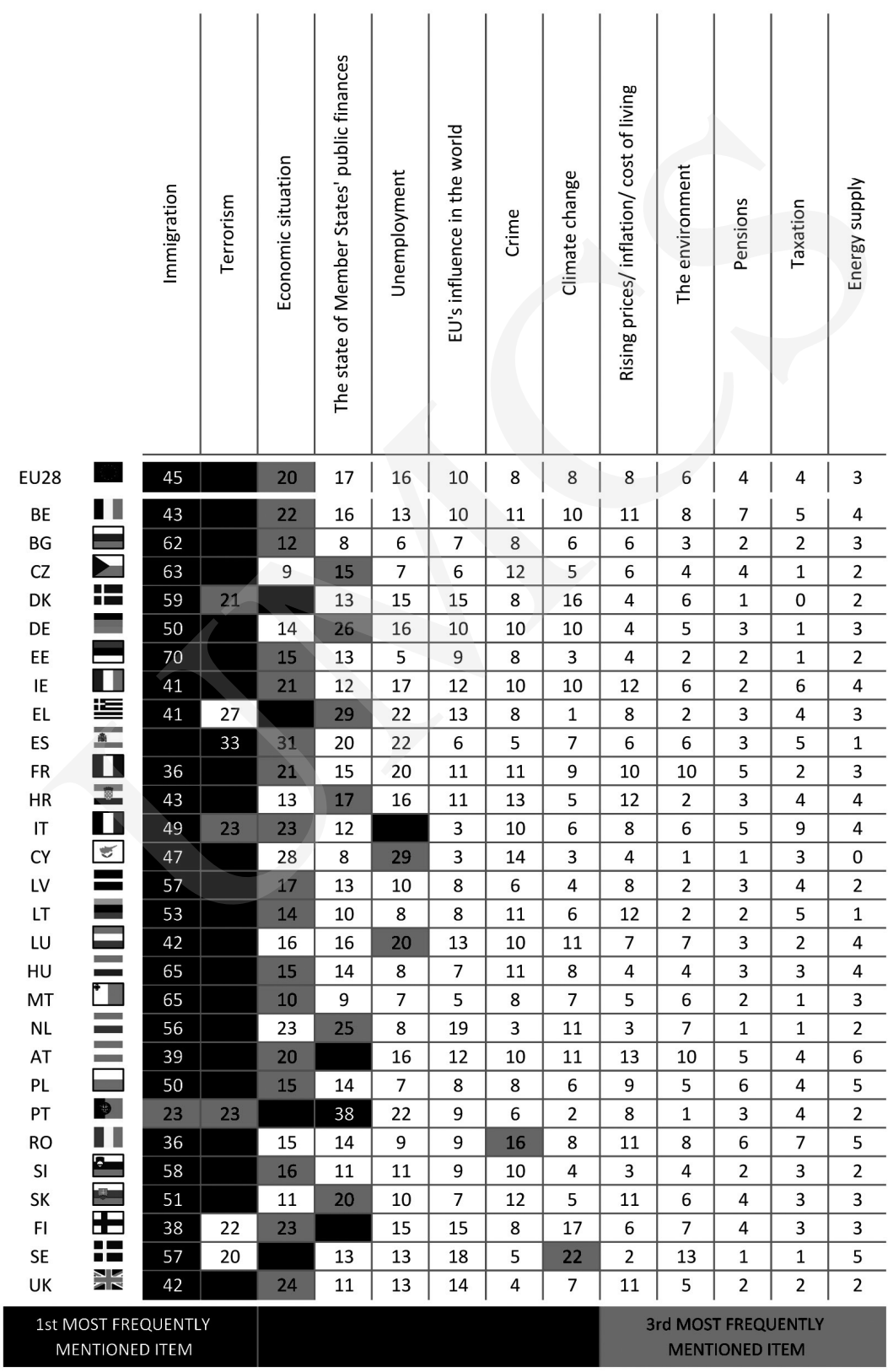

Rys. 4. Jakie są najważniejsze problemy, z którymi boryka się Twój kraj w bieżącym czasie? (w \%)

Źródło: opracowanie własne na podstawie: Standard Eurobarometer 86, Public opinion in the European Union, https://ec.europa.eu/finland/sites/finland/files/eb86_first_en.pdf [dostęp: 20.11.2017]. 
Pobrane z czasopisma Annales I - Philosophy and Sociology http://philosophia.annales.umcs.pl Data: 26/04/2023 14:49:10

W świadomości społecznej rzeczywistość, która jest odległa (w perspektywie czy to przestrzennej, czy czasowej), może się różnić od tej doświadczanej każdego dnia. Tym bardziej, kiedy nie jest możliwe poznanie jej w sposób zmysłowy, a jedynie zapośredniczony (np. przez media). Pokazują to opinie Polaków na temat środowiska naturalnego, które różnią się w zależności od skali geograficznej. Im większy obszar jest poddany ocenie, tym gorsza ocena tego środowiska.

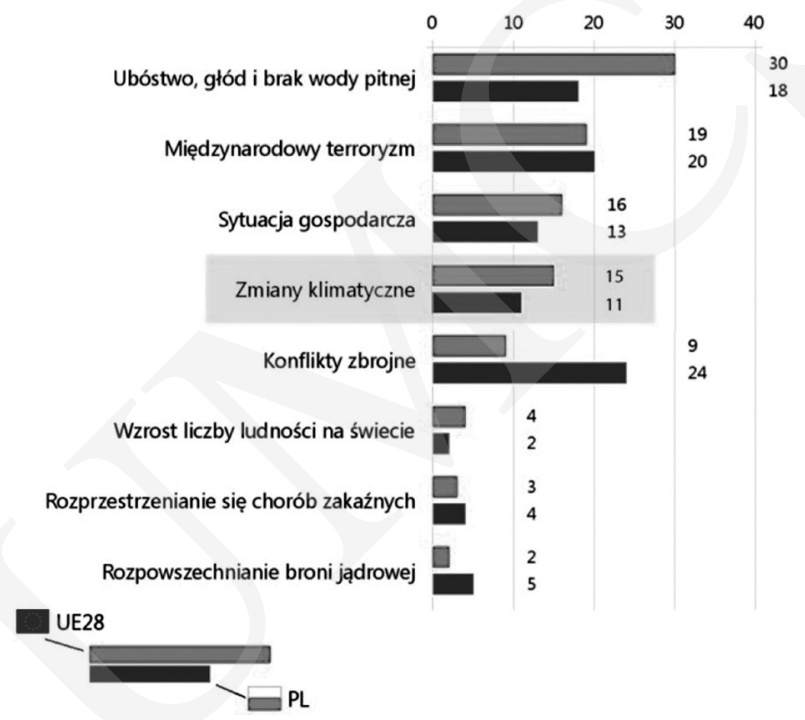

Rys. 5. Który z wymienionych problemów uważa Pani/Pan za najpoważniej zagrażający światu? (Polska - w \%)

Źródło: opracowanie własne na podstawie: Special Eurobarometer 435, Climate Change, https:// ec.europa.eu/clima/sites/clima/files/support/docs/report_2015_en.pdf [dostęp: 20.11.2017].

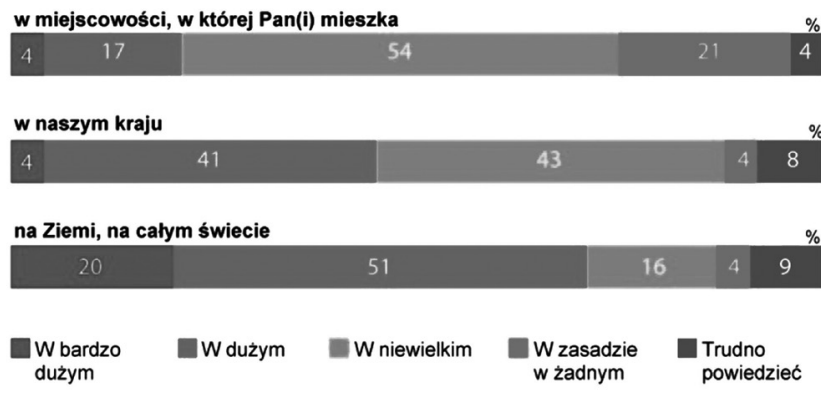

Rys. 6. W jakim stopniu stan środowiska naturalnego jest powodem Pani/Pana niepokoju? (Polska)

Źródło: opracowanie własne na podstawie: Stan środowiska i zmiany klimatu, „CBOS. Komunikat z Badań” 2016, nr 39, http://cbos.pl/SPISKOM.POL/2016/K_039_16.PDF [dostęp: 20.11.2017]. 
Pobrane z czasopisma Annales I - Philosophy and Sociology http://philosophia.annales.umcs.pl Data: 26/04/2023 14:49:10

Ryzyko ekologiczne jako ryzyko społeczne...

205

Możliwe jest powstawanie sporów, które toczą się głównie wokół podzielanych ogólnie (negatywnych) wartości (odnoszących się do ryzyka). Nie sposób nie dostrzec szeregu czynników kontekstowych wpływających na percepcję zmian klimatycznych w różnych krajach, choćby w przypadku różnic w zakresie sprawowanej polityki energetycznej (wynikających np. z bogactwa złóż ropy czy węgla), warunków geograficznych (np. dla położonej na depresji Holandii postępujące w wyniku topnienia lodowców podnoszenie się poziomu morza stwarza groźbę licznych powodzi i podtopień) i atmosferycznych (np. większej intensywności huraganów na południowo-wschodnim wybrzeżu USA czy licznych suszy i wynikających z nich pożarów w Portugalii) lub stanu gospodarki (jak pokazują powyższe zestawienia, np. dla Grecji pogrążonej w kryzysie ekonomicznym sprawy klimatyczne są marginalne).

\section{RYZYKO KLIMATYCZNE JAKO RYZYKO SPOŁECZNE}

Tak zdefiniowane ryzyko może być konsolidowane z kwestią problemu społecznego. Jak przenikliwie zauważa R.K. Merton, z problemem społecznym mamy do czynienia, gdy spotykamy się z rozbieżnością pomiędzy tzw. społecznymi standardami a faktycznym stanem rzeczywistości ${ }^{31}$. Dyskusyjną kwestią jest jednak odpowiednie zdefiniowanie tych standardów i tym samym określenie istoty problemu społecznego. Zdaniem P. Matczaka:

[...] problemy społeczne są relatywizowane - istnieją różnice międzygrupowe i różnice historyczne, różnice skali - np. między morderstwem a drobną kradzieżą. O problemie społecznym można mówić, gdy wspomniana rozbieżność definiowana jest przez grupę wpływową - nie zaś [...] prywatnie [...]. Problemy społeczne tworzone są przez ,naznaczanie” określonych sytuacji, mają swoich ,jurorów”, wraz z całym bagażem wpływu struktury społecznejej2.

Dlatego sytuacja określana przez jedną grupę jako problematyczna bądź negatywna, przez inną może być traktowana neutralnie lub wręcz pozytywnie.

Problem społeczny może być też rozważany z perspektywy konfliktu systemów aksjologicznych, tj. sporu między podzielającymi pewne wartości a tymi, którzy je negują. Jednak, jak wspomina dalej Matczak, „oczywiście problem jurorów pozostaje" "33. Autor wskazuje tutaj na tę ,wpływową grupę", która zawiera w sobie szczególnie istotnych aktorów przy definiowaniu problemów społecznych, jako zagrożenie dla ich wartości. Przykładem może być tocząca się aktualnie debata na

\footnotetext{
31 R.K. Merton, R.A. Nisbet, Contemporary Social Problems, New York 1966.

32 P. Matczak, Problemy ekologiczne jako problemy społeczne, Poznań 2000.

33 Ibidem, s. 42.
} 
temat eksponowania symboli religijnych w instytucjach publicznych czy finansowania programu zapłodnienia in vitro oraz dyskusje wokół legalności aborcji i eutanazji. Na dany aspekt zwracają uwagę także inni badacze rzeczywistości społecznej (J.A. Hannigan ${ }^{34}$, T.J. Sullivan i K.S. Thompson ${ }^{35}$ ), podkreślając nie tylko rolę tego, kto definiuje problem jako „rzeczywisty”, ale także tego, kto go legitymizuje i demonstruje (np. media). Kwestia ta zostanie poruszona szerzej w kolejnej części pracy.

Aspekt formułowania ryzyka, z perspektywy pewnej „konstrukcji społecznej”, może być zatem ujmowany jako pewien problem społeczny. Co więcej, jako właściwy problem społeczny mogą być rozpatrywane również kwestie, które na ogół nie są utożsamiane z kategorią społeczną, jak np. ryzyko klimatyczne czy, szerzej, zagadnienia natury ekologicznej (środowiskowej).

Tzw. problem ekologiczny wynika z rozdźwięku pomiędzy rzeczywistością a wartościami, które określają, jak ta rzeczywistość powinna wyglądać. Aspekt ten jest ściśle związany z tzw. świadomością ekologiczną. Jak pisze Burger, to „kategoria opisowa mówiąca o tym, jak konkretna grupa społeczna, czy też całe społeczeństwo (np. polskie), widzi swoje miejsce w przyrodzie i jak postrzega swoje związki ze środowiskiem naturalnym"36. Daną definicję można uzupełnić jeszcze o inne cechy, takie jak: intuicyjne przekonania, wiedza na temat stanu środowiska i jego wpływu na życie ludzi, dyspozycje zachowaniowe, faktyczne działania (,postawa proekologiczna”).

Jak wspomniałem we wprowadzeniu, kwestie związane ze środowiskiem nabierają dzisiaj szczególnego znaczenia. Wynika to ze specyficznej internalizacji problemów, nieutożsamianych dotąd jako społeczne, właśnie w obręb społeczeństwa. Oznacza to, że omawiane tutaj kwestie natury nie są traktowane w głównej mierze jako tylko otoczenie systemu społecznego, będące zewnętrzne wobec niego. Natura (w tym jej problemy i związane z nią ryzyko) jest obecnie sytuowana w polu samego społeczeństwa jako jego wewnętrzny aspekt. Związane z tym faktem myślenie „przyrodoznawcze”, czy raczej pewien kulturowy wzorzec natury, jest rezultatem postrzegania świata jako ekologicznie zagrożonego. Środowisko w tym sensie nie jest zawsze odbiciem faktycznych procesów przemysłowych (czy, ogólnie, działalności ludzkiej), efektem ich wzajemnych połączeń i uszkodzeń, lecz jest pewnym sposobem widzenia świata. Jak wspomina Beck:

[...] natura nie jest naturą, lecz pojęciem, normą, wspomnieniem, utopią, kontrprojektem, dziś w jeszcze większym stopniu niż kiedykolwiek wcześniej [...]. To, co jest i co wzbudza polityczną burzę, to rozmaite formy uspołecznienia (zniszczeń) natury, kulturowe pojęcia natury, sprzeczne

34 Zob. J.A. Hannigan, Environmental Sociology. A Social Constructionist Perspective, London 1995.

35 T.J. Sullivan, K. S. Thompson, Introduction to Social Problems, New York 1988.

36 T. Burger, Świadomość ekologiczna-między lękiem a działaniem, Warszawa 1992, s. 11. 
Pobrane z czasopisma Annales I - Philosophy and Sociology http://philosophia.annales.umcs.pl Data: 26/04/2023 14:49:10

Ryzyko ekologiczne jako ryzyko społeczne...

rozumienia natury i ich kulturowe (narodowe) tradycje, które określają konflikty ekologiczne na całym świecie pod powierzchnią zagrożeń, technicznych formuł i sporów ekspertów ${ }^{37}$.

Podobną tezę formułuje R.J. Alexander, autor książki Framing Discourse on Environment, który pisze:

[...] postrzeganie czy niepostrzeganie kryzysu ekologicznego czy problemów środowiska naturalnego, takich jak globalne ocieplenie czy dziura ozonowa, nie jest efektem doświadczenia zmysłowego. Źródłem wiedzy na ten temat jest [...] dyskurs naukowców. Te głosy są często filtrowane i zniekształcone w środkach masowego przekazu. Na ich przekaz z kolei nakładają się dyskursy różnych grup interesu: polityków, przedsiębiorców itd. ${ }^{38}$

W taki sposób tworzony jest obraz świata natury wraz z jego społeczną reprezentacją. Alexander wpisuje się w tym zakresie w analizowany tutaj dyskurs dotyczący ryzyka. Jego zdaniem potencjalne zagrożenia środowiskowe mogą być utożsamiane ze:

[...] społecznymi konstrukcjami i definicjami opartymi na odpowiednich stosunkach definiowania. Istnieją w formie (naukowej i alternatywnej wobec niej) wiedzy. W konsekwencji ich „realność” można udramatyczniać lub minimalizować, zmieniać lub najzwyczajniej negować [...]. Są one owocem walk o definicje i definicyjnych konfliktów w ramach określonych stosunków władzy definiowania ${ }^{39}$.

Stawką w tej grze jest możliwość wskazywania, czym jest, a czym nie jest ryzyko. W tym sensie - odwołując się do koncepcji P. Bourdieu - ryzyko jest polem gry w obrębie, którego poszczególni aktorzy mogą ze sobą rywalizować o najlepszą pozycję w hierarchii „stosunków definiowania”, tj. nadawania konkretnemu ryzyku odpowiedniego znaczenia, które zostanie narzucone innym uczestnikom ${ }^{40}$.

\section{RYZYKO KLIMATYCZNE I MEDIA}

Właściwym problemem zdaje się być jednak pytanie o to, „W jaki sposób ryzyko zyskuje miano »realnego «” ${ }^{41}$ Czy, ujmując to inaczej, jak , przyszłość katastrofy staje się teraźniejszością"? ${ }^{42} \mathrm{~W}$ tym miejscu warto zwrócić uwagę na to, iż ryzyko sensu stricto jest pozbawione możliwości zmysłowego poznania. Ryzyko

37 U. Beck, Społeczeństwo światowego ryzyka..., s. 125-126.

38 R.J. Alexander, Framing Discourse on Environment. A Critical Discourse Approach, London-New York 2009, s. 3.

39 U. Beck, Społeczeństwo światowego ryzyka..., s. 52.

$40 \quad$ P. Bourdieu, Dystynkcja. Społeczna krytyka władzy sądzenia, Warszawa 2006.

${ }_{41}$ U. Beck, Społeczeństwo światowego ryzyka..., s. 23.

42 Ibidem. 
jest kategorią odniesioną wprost do przyszłości, jest antycypacją zagrożenia, które jeszcze nie nadeszło. Tym samym unaocznione mogą być tylko jego przyczyny i wszelkie wyobrażenia, desygnaty i konteksty, które wspólnie składają się na to, co możemy nazwać „reprezentacją” tego ryzyka.

Aby potencjalna katastrofa mogła się zmaterializować w teraźniejszości (np. na poziomie decyzji i działań), musi być podatna na różnego rodzaju „inscenizacje"43. To właśnie aktorzy, którzy posiadają możliwość inscenizowania, dystrybuują wiedzę na temat tego: co jest, a co nie jest niebezpieczne; jakim obszarom życia zagraża; w jak dużym stopniu; jak należy je monitorować bądź mu przeciwdziałać. Inscenizacja ryzyka, mimo że nie jest intencjonalnym „deformowaniem" rzeczywistości, potwierdza przytoczoną powyżej tezę Douglas o tym, iż zatarciu często ulegają granice między subiektywną świadomością (opartą o definicję społeczną) a realnym ryzykiem.

Aktorem, który niewątpliwie posiada duży potencjał do tego, by uczestniczyć w procesie inscenizowania ryzyka, są media. We współczesnym świecie media (masowe) są określane przez metaforę „okna na świat”. Rozszerzają ludzką możliwość „doświadczania” rzeczywistości (poprzez poznawanie odległych lub niedostępnych wydarzeń) oraz - jak zaznacza T. Goban-Klas - są określane jako drogowskazy wskazujące ,sposób i wydobywające sens z wydarzeń”44. Polski badacz przekonuje, iż dzisiejsze media konstytuują społeczeństwo w tym sensie, że ich liczba, zasięg oraz regularność przekazu „stały się dominującym źródłem kształtowania indywidualnej wyobraźni szerokich rzesz odbiorców, a to znaczy praktycznie całego społeczeństwa" ${ }^{\text {"⿻ž }}$.

Jak wskazują badania przeprowadzone przez Centrum Badania Opinii Społecznej, większość Polaków czerpie z mediów wiedzę o wydarzeniach z kraju i świata. Niespełna dwóch na trzech badanych (64\%) w tym wymiarze wskazuje na telewizję (również oglądaną w Internecie), w dalszej kolejności Polacy budują swój ogląd rzeczywistości na bazie Internetu (21\%), radia (8\%), a w najmniejszym stopniu - na podstawie prasy $(4 \%)^{46}$. Zdaniem M. McLuhana media są dzisiaj naturalnym środowiskiem komunikacji człowieka ${ }^{47}$. Codziennie korzystamy z Internetu: porozumiewamy się z innymi za sprawą social media; poszukujemy sieci, by się czegoś dowiedzieć lub wyszukać ważne dla nas wiadomości; podczas podróży

43 Ibidem.

44 T. Goban-Klas, Społeczeństwo medialne, Warszawa 2005, s. 28.

45 Ibidem.

46 Ocena wiarygodności telewizyjnych programów informacyjnych i publicystycznych, „CBOS. Komunikat z Badań” 2017, nr 52, http://cbos.pl/SPISKOM.POL/2017/K_052_17.PDF [dostęp: 20.11.2017], s. 1.

47 M. McLuhan, Zrozumieć media. Przedłużenia człowieka, Warszawa 2004. 
Pobrane z czasopisma Annales I - Philosophy and Sociology http://philosophia.annales.umcs.pl Data: 26/04/2023 14:49:10

Ryzyko ekologiczne jako ryzyko społeczne...

209

samochodem słuchamy radia, a wieczorem koncentrujemy się na podsumowaniach dnia w telewizyjnych serwisach informacyjnych. Dzisiaj to kontakty i przekazy zapośredniczone przez media są fundamentalną formą komunikacji, tworząc - jak określa to wielu badaczy - ,społeczeństwo medialne” (zmediatyzowane) ${ }^{48}$.

Media masowe, konstruując obraz naszego świata, budują świadomość istnienia różnorodnych zjawisk, a zapośredniczone w ten sposób doświadczenia stają się realne. Podobnie jest w przypadku samego ryzyka, które - jak podkreśla Beck - jest kategorią wysoce „zmediatyzowaną" ${ }^{49}$. Środki masowego przekazu bowiem wzmacniają lub osłabiają poczucie niebezpieczeństwa, wyczulając ludzi na „czające się" możliwe zagrożenie. Przykład takiego wzmocnienia obrazują badania B. Glassnera. Z przytoczonych przez autora statystyk można dowiedzieć się, iż między 1990 i 1998 r. w Stanach Zjednoczonych liczba zabójstw oraz przestępstw z użyciem broni spadła o ponad $20 \%$. W tym samym czasie jednak aż o $600 \%$ wzrosła liczba doniesień medialnych o popełnianych przestępstwach. Skutkiem tego ogólny poziom lęku (przed przestępczością) się podniósł ${ }^{50}$.

Kiedy jednak rozważamy medialność problemów ekologicznych, nie sposób nie wspomnieć o relatywistycznym charakterze tego dyskursu. Najczęstszym sposobem przedstawiania tych kwestii jest ujmowanie ich w formie dwu antagonistycznych stanowisk, np. decyzji rządowych i protestu ekologów, działań korporacji/ fabryki i oburzenia społeczności lokalnej, „,interesu polskiego” i wymogów instytucji europejskich. Na tak sprofilowanej scenie ekologia jawi się jako przestrzeń konfliktowa, znajduje się pomiędzy różnymi interesami i sposobami widzenia świata. Pomimo „nośności” tego typu debat w mediach, problemy środowiskowe stanowią peryferyjny wymiar dyskursu medialnego ${ }^{51}$, podobnie jak w przypadku obrazowania ryzyka klimatycznego.

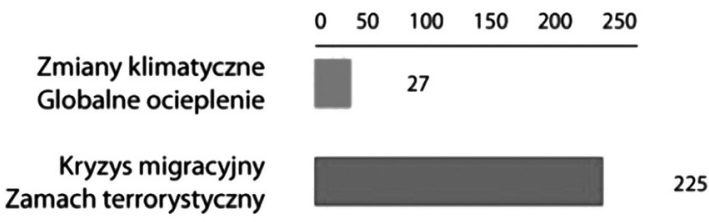

Rys. 7. Doniesienia medialne na temat ryzyka w tygodniku „Newsweek” (styczeń-listopad 2017 r.)

Źródło: opracowanie własne.

48 T. Goban-Klas, op. cit., s. 45.

49 U. Beck, Społeczeństwo światowego ryzyka..., s. 109.

50 B. Glassner, The Culture of Fear: Why Americans Are Afraid of the Wrong Things?, New York 1999.

51 M. Steciąg, Dyskurs ekologiczny w debacie publicznej, Zielona Góra 2012. 
Rys. 7 obrazuje liczbę doniesień poświęconych dwu różnym rodzajom ryzyka. Zmiany klimatu stanowią margines tzw. pola możliwych zagrożeń w informacjach medialnych. Przyczyną tego może być brak wyraźnego desygnatu, czyli „nie są dostrzegane w wymiarze empirycznym i trudno je wyraziście skonceptualizować, gdyż nie można ich poznać za pomocą zmysłów"52. Kryzys migracyjny i zagrożenie terrorystyczne posiadają ten desygnat, a są nim m.in. rzesze uchodźców w tymczasowo stworzonych dla nich obozach czy eksplozje na dworcach i lotniskach europejskich miast. Dodatkowo (co już zostało wspomniane) ryzyko klimatyczne jest zjawiskiem, którego „realność wciąż podlega kwestionowaniu/dowodzeniu”53. Dlatego w świadomości ludzkiej może jawić się ono jako „puste określenie”, za którym nie kryje się żadne realne zjawisko. W tym sensie medialność tego aspektu przybiera ograniczoną skuteczność bądź jest utożsamiana wręcz z manipulowaniem rzeczywistością na rzecz „klimatycznych interesariuszy”.

\section{UWAGI KOŃCOWE}

Podsumowując niniejsze rozważania, należy stwierdzić, że kwestie ekologiczne zyskują współcześnie specyficzne znaczenie. Dzieje się tak, ponieważ są postrzegane jako szerszy kontekst problemów społecznych (w tym politycznych czy gospodarczych). Przyrodzie nadawane są pewne znaczenia i reprezentacje, jawi się ona jako „zmierzająca do destrukcji” i tym samym zagraża nam wszystkim, choćby w postaci ryzyka klimatycznego. Zmiany klimatyczne, pomimo nacechowania semantycznego jako „globalnej katastrofy” czy nawet „końca świata”, wydają się jednak nie stanowić (w świadomości społecznej) obiektu codziennego niepokoju. Wpływ na to ma niewątpliwie względna peryferyjność dyskursu ryzyka klimatycznego w mediach, który jest pozbawiony konkretnego desygnatu w rzeczywistości. Antycypacja katastrofy przez to nie jest wymierna, a toczący się wokół tego zjawiska spór wydaje się zyskiwać pewien naddatek ontologiczny, tj. zmiana klimatyczna staje się bardziej przedmiotem wiary niż pewnej wiedzy o świecie.

Pewności tej nie pomaga także toczący się wokół tego zjawiska spór światopoglądowy. Zmiana klimatyczna została wciągnięta do debaty publicznej jako przedmiot walki politycznej i funkcjonuje $\mathrm{z}$ jednej strony jako niezmiernie istotny temat polityczny, a z drugiej jako „wymysł lewaków" "54. M. Stęciąg obrazuje ten problem przez zestawienie profili znaczeniowych frazy ,globalne ocieplenie”

\footnotetext{
52 Ibidem, s. 156.

53 Ibidem.

$54 \quad$ Ibidem, s. 159.
} 
Pobrane z czasopisma Annales I - Philosophy and Sociology http://philosophia.annales.umcs.pl Data: 26/04/2023 14:49:10

Ryzyko ekologiczne jako ryzyko społeczne...

w polskiej prasie (tab. 1). Zdaniem autorki kontrastujące ze sobą stanowiska tworzą obraz zmian klimatycznych jako kwestii abstrakcyjnych.

Tab. 1. Profile znaczeniowe frazy ,globalne ocieplenie”

\begin{tabular}{|l|l|l|}
\hline \multicolumn{1}{|c|}{ Profil znaczeniowy } & \multicolumn{1}{|c|}{ Zwolennicy teorii } & \multicolumn{1}{c|}{ Przeciwnicy teorii } \\
\hline $\begin{array}{l}\text { Globalne ocieplenie jako } \\
\text { realny byt: prawdziwe za- } \\
\text { grożenie - nie istnieje }\end{array}$ & $\begin{array}{l}\text { Globalne ocieplenie jest realnym } \\
\text { i śmiertelnym niebezpieczeń- } \\
\text { stwem („Gazeta Wyborcza”) }\end{array}$ & $\begin{array}{l}\text { Globalne ocieplenie to kłamstwo } \\
\text { służące wykorzystywaniu naiw- } \\
\text { niaków („Rzeczpospolita”) }\end{array}$ \\
\hline $\begin{array}{l}\text { Globalne ocieplenie jako } \\
\text { przedmiot opisu: nie jest } \\
\text { wyolbrzymione - to pro- } \\
\text { paganda }\end{array}$ & $\begin{array}{l}\text { Globalne ocieplenie nie jest do- } \\
\text { mysłem, histerią ani tendencyjnie } \\
\text { przerysowanym niebezpieczeń- } \\
\text { stwem („Gazeta Wyborcza”) }\end{array}$ & $\begin{array}{l}\text { Ostatnio na łamach „Rzeczpospo- } \\
\text { litej” pojawiło się kilka tekstów } \\
\text { pokazujących absurdy czy wykpi- } \\
\text { wających globalnoociepleniową } \\
\text { propagandę (,Rzeczpospolita”) }\end{array}$ \\
\hline $\begin{array}{l}\text { Globalne ocieplenie jako } \\
\text { teoria naukowa: potwier- } \\
\text { dzona - niepotwierdzona }\end{array}$ & $\begin{array}{l}\text { Przeciętny polski widz i czytelnik } \\
\text { może się dowiedzieć z mediów, że } \\
\text { w sprawie zmian klimatu toczy się } \\
\text { równorzędna dyskusja między na- } \\
\text { ukowcami („Gazeta Wyborcza”) }\end{array}$ & $\begin{array}{l}\text { Nawet jeśli nauka nie potwierdza } \\
\text { teorii globalnego ocieplenia, to } \\
\text { zachowac uniknięcia ryzyka należy } \\
\text { (,Rzeczpospolita”) }\end{array}$ \\
\hline
\end{tabular}

Źródło: opracowanie własne na podstawie: M. Steciąg, Dyskurs ekologiczny w debacie publicznej, Zielona Góra 2012.

Uabstrakcyjnieniu zjawiska służy również rozmyta odpowiedzialność nie tylko za przyczyny, ale przede wszystkim za kwestie radzenia sobie z problemem. $\mathrm{W}$ dyskursie często pojawiającym się sformułowaniem, łączonym z ryzykiem klimatycznym, jest walka/przeciwstawianie się tym zmianom. Na ogół nie jest zdefiniowane to, kto walczy. Odarcie problemu z tego kontekstu zaciemnia związki z codziennym doświadczeniem człowieka i staje się zarzewiem konfliktów. Jak pokazują liczne przykłady (dotyczące niekalkulowalności ryzyka), rzeczywistość nie jest podatna na proste antycypacje, dlatego nie ma pewności i zgody na konkretne decyzje i działania naprawcze. W tym sensie trudności w urzeczywistnieniu przyszłych zagrożeń przyrodniczych mogą stanowić jedną z głównych barier dla stworzenia ogólnospołecznego konsensusu klimatycznego.

\section{BIBLIOGR AFIA}

Alexander R. J., Framing Discourse on Environment. A Critical Discourse Approach, London-New York 2009.

Arnoldi J., Ryzyko, Warszawa 2011.

Beck U., Gegengifte. Die organisierte Unverantwortlichkeit, Frankfurt am Main 1988.

Beck U., Społeczeństwo ryzyka. W drodze do innej nowoczesności, Warszawa 2002.

Beck U., Społeczeństwo światowego ryzyka. W poszukiwaniu utraconego bezpieczeństwa, Warszawa 2012. 
Beck U., Grande E., Europa kosmopolityczna. Społeczeństwo i polityka w drugiej nowoczesności, Warszawa 2009.

Bell M., An Invitation to Environmental Sociology, Thousand Oaks 1998.

Bernstein P.L., Przeciw bogom. Niezwykte dzieje ryzyka, Warszawa 2011.

Bourdieu P., Dystynkcja. Społeczna krytyka władzy sadzenia, Warszawa 2006.

Burger T., Świadomość ekologiczna - między lękiem a działaniem, Warszawa 1992.

Cichocki P., Konteksty społeczeństwa ryzyka, Poznań 2005.

Douglas M., Wildavsky A., Risk and Culture, Berkeley 1983.

Giddens A., Katastrofa klimatyczna, Warszawa 2010.

Giddens A., Nowoczesność i tożsamość. „Ja” i społeczeństwo w epoce późnej nowoczesności, Warszawa 2012.

Giddens A., Socjologia, Warszawa 2006.

Glassner B., The Culture of Fear: Why Americans Are Afraid of the Wrong Things?, New York 1999.

Goban-Klas T., Społeczeństwo medialne, Warszawa 2005.

Hannigan J.A., Environmental Sociology. A Social Constructionist Perspective, London 1995.

IPCC, Zmiany klimatu 2013. Fizyczne podstawy naukowe, http://ipcc.ch/pdf/reports-nonUN-translations/polish/ar5-wg1-spm.pdf [dostęp: 20.11.2017].

Lomborg B., Cool It, New York 2007.

Matczak P., Problemy ekologiczne jako problemy społeczne, Poznań 2000.

McLuhan M., Zrozumieć media. Przedlużenia człowieka, Warszawa 2004.

Merton R.K., Nisbet R.A., Contemporary Social Problems, New York 1966.

Ocena wiarygodności telewizyjnych programów informacyjnych i publicystycznych, „CBOS. Komunikat z Badań” 2017, nr 52, http://cbos.pl/SPISKOM.POL/2017/K_052_17.PDF [dostęp: 20.11.2017].

Rowe W.D., An “Anatomy” of Risk, Environmental Protection Agency, Washington 1977.

Singer F., Avery D. T., Unstoppable Global Warming, New York 2007.

Special Eurobarometer 435, Climate Change, https:/ec.europa.eu/clima/sites/clima/files/support/ docs/report_2015_en.pdf [dostęp: 20.11.2017].

Stan środowiska i zmiany klimatu, „CBOS. Komunikat z Badań” 2016, nr 39, http://cbos.pl/SPISKOM.POL/2016/K_039_16.PDF [dostęp: 20.11.2017].

Standard Eurobarometer 86, Public opinion in the European Union, https:/ec.europa.eu/finland/ sites/finland/files/eb86_first_en.pdf [dostęp: 20.11.2017].

Steciąg M., Dyskurs ekologiczny w debacie publicznej, Zielona Góra 2012.

Strydom P., Risk, Environmental and Society: Ongoing Debates, Current Issues and Future Prospects, Philadelphia 2002.

Sullivan T.J., Thompson K. S., Introduction to Social Problems, New York 1988.

\section{SUMMARY}

The necessity of dealing with risk undoubtedly accompanies society at every stage of its development and so it does today. The worldwide risk society is a proper denotation of today's reality according to German sociologist U. Beck. The category describes the world of global threats, which source is civilization itself as well as scientific and technological progress. It is also a period in which the social consciousness of risk is fundamentally crystallized and in which the rigid distinction between the calculated (objective) risk and its (subjective) awareness is all the more blurred. One of the challenges of this reality is the issue of environmental change (ecological risk). The modern debate surrounding potential global warming, the importance attributed to the ecological security 
Pobrane z czasopisma Annales I - Philosophy and Sociology http://philosophia.annales.umcs.pl Data: 26/04/2023 14:49:10

Ryzyko ekologiczne jako ryzyko społeczne...

aspect and the number of actors involved in this issue, forces to reflect that climate change is not just a purely natural issue (just look at possible political, economic, and social costs of global warming).

Keywords: risk; risk society; climate change; ecology

\section{STRESZCZENIE}

Konieczność radzenia sobie z ryzykiem jest niewątpliwie kwestią towarzyszącą społeczeństwu na każdym etapie jego rozwoju, nie inaczej jest współcześnie. Społeczeństwo (światowego) ryzyka, bo tak dzisiejszą rzeczywistość określa niemiecki socjolog U. Beck, jest kategorią opisującą świat globalnych zagrożeń, których źródłem jest sama cywilizacja i postęp naukowo-technologiczny. Jest to także okres, w którym w sposób zasadniczy krystalizuje się społeczna świadomość ryzyka, w ramach której bardziej niż kiedykolwiek zatarciu ulega sztywne rozróżnienie między obliczalnym (obiektywnym) ryzykiem a jego (subiektywną) świadomością. Jednym z wyzwań tej rzeczywistości jest kwestia zmian środowiska naturalnego (ryzyko ekologiczne). Tocząca się współcześnie debata wokół potencjalnego ocieplenia klimatu, znaczenie, jakie przypisuje się aspektowi bezpieczeństwa ekologicznego oraz liczba aktorów zaangażowanych w ten problem wymuszają refleksję, iż zmiana klimatyczna to nie tylko problem czysto przyrodniczy (wystarczy spojrzeć na ewentualne polityczne, ekonomiczne i społeczne koszty globalnego ocieplenia).

Słowa kluczowe: ryzyko; społeczeństwo ryzyka; zmiana klimatu; ekologia 